Article

\title{
Mapping Thermal Energy Resource Potentials from Wastewater Treatment Plants
}

\section{Georg Neugebauer ${ }^{1, *}$, Florian Kretschmer ${ }^{2, \dagger}$, René Kollmann ${ }^{3, \dagger}$, Michael Narodoslawsky ${ }^{3, \dagger}$, Thomas Ertl ${ }^{2, \dagger}$ and Gernot Stoeglehner ${ }^{1, \dagger}$}

1 Institute of Spatial Planning and Rural Development, University of Natural Resources and Life Sciences Vienna, Peter-Jordan-Straße 82, 1190 Vienna, Austria; E-Mail: gernot.stoeglehner@boku.ac.at

2 Institute of Sanitary Engineering and Water Pollution Control, University of Natural Resources and Life Sciences Vienna, Muthgasse 18, 1190 Vienna, Austria; E-Mails: florian.kretschmer@boku.ac.at (F.K.); thomas.ertl@boku.ac.at (T.E.)

3 Institute of Process and Particle Engineering, Graz University of Technology, Inffeldgasse 13/3, 8010 Graz, Austria; E-Mails: rene.kollmann@tugraz.at (R.K.); narodoslawsky@tugraz.at (M.N.)

$\dagger$ These authors contributed equally to this work.

* Author to whom correspondence should be addressed; E-Mail: georg.neugebauer@boku.ac.at; Tel.: +43-1-47654-5369; Fax: +43-1-47654-5353.

Academic Editor: Vincenzo Torretta

Received: 31 May 2015 / Accepted: 17 September 2015 / Published: 24 September 2015

\begin{abstract}
Wastewater heat recovery via heat exchangers and heat pumps constitutes an environmentally friendly, approved and economically competitive, but often underestimated technology. By introducing the spatial dimension in feasibility studies, the results of calculations change considerably. This paper presents a methodology to estimate thermal energy resource potentials of wastewater treatment plants taking spatial contexts into account. In close proximity to settlement areas, wastewater energy can ideally be applied for heating in mixed-function areas, which very likely have a continuous heat demand and allow for an increased amount of full-load hours compared to most single-use areas. For the Austrian case, it is demonstrated that the proposed methodology leads to feasible results and that the suggested technology might reduce up to $17 \%$ of the Austrian global warming potential of room heating. The method is transferrable to other countries as the input data and calculation formula are made available. A broad application of wastewater energy with regard to spatial structures and spatial development potentials can lead to (1) increasing
\end{abstract}


energy efficiency by using a maximum of waste heat and (2) a significant reduction of (fossil) energy consumption which results in a considerable reduction of the global warming potential of the heat supply (GWP) if electricity from renewables is used for the operation of heat pumps.

Keywords: wastewater energy; heat recovery; spatial planning; energy planning; wastewater treatment plant; climate change mitigation; renewable energy; life-cycle impact assessment

\section{Introduction}

As the scientific debate about the energy turn towards energy efficiency and renewable energy systems moves forward, the search for new renewable energy resources and innovative technologies accelerates. Recently, energy generation from wastewater, e.g., due to heat recovery, attracts more attention internationally and several practical applications are documented in the international literature [1-3]. In a few countries as, for instance, Switzerland [4] and Germany [5] this energy source is already included in energy policy making. The Austrian implementation of the European Directive 2012/27/EU on energy efficiency explicitly names heat recovery from wastewater as a measure to reduce final energy consumption [6].

Case studies show that technologies for wastewater heat recovery have been successfully implemented in three locations of the wastewater infrastructure [7]: (1) inside buildings [8]; (2) from the sewer [9] and (3) at the wastewater treatment plant (WWTP) [10]. This article focuses on energy provision options related to thermal energy recovery from WWTPs which is reasoned as follows: One major restriction of heat recovery in buildings and sewers concerns the reduction of wastewater temperature. Especially in cold winter days, the reduction might harm the wastewater treatment process and reduce the performance of the WWTP [11-13]. At WWTPs wastewater heat recovery can be placed after the treatment process [10], so that the temperature reduction of the cleaned wastewater might even lead to positive environmental effects concerning the receiving water courses [14]. At the WWTP, treated wastewater is available as medium for the heat extraction continuously and in greater quantities than in the sewage. Finally, WWTPs rank among the major power consumers on municipal level as a German study points out a share of about $20 \%$ of the communal electricity demand [15].

Concerning energy demand, wastewater and sludge treatment consume electricity (e.g., for inflow pumping, mechanical pre-treatment, sludge thickening, digestion and dewatering as well as infrastructure) and thermal energy (e.g., for heating of buildings, hot water production preheating of sludge, digester heating or compensation of transmission losses) [16]. At the same time, the respective wastewater and sludge treatment processes can provide energy and other resources [17-21]. Therefore, in addition to their main function of ensuring public health and safety as well as environmental protection, WWTPs can be considered as essential energy and resource cells.

Energy resource potentials at the WWTP can (1) directly be linked to the wastewater treatment process, which is heat recovery via heat pumps and heat exchangers and the use of digester gas in combined heat and power systems (CHP); (2) comprise non-site-specific energy sources that can be kept in multi-shift use, especially, solar thermal and photovoltaics as well as wind and hydropower 
energy generation on WWTP buildings and facilities [2,10]. Figure 1 illustrates the relationships between consumption and provision of energy and resources in the wastewater treatment system. Wastewater, including nutrients, energy from public supply (e.g., electricity, natural gas) and-where appropriate-bio-waste as a co-substrate for anaerobic sludge treatment are considered as "raw materials". With regard to treatment "technologies", a distinction can be made between aerobic and anaerobic sludge stabilization. "Intermediate products" such as treated wastewater, digester gas, stabilized sewage sludge and solar energy can be further processed to the "final products" heating and cooling energy, reusable treated wastewater, electric power, natural gas substitute and processible stabilized sludge [22].

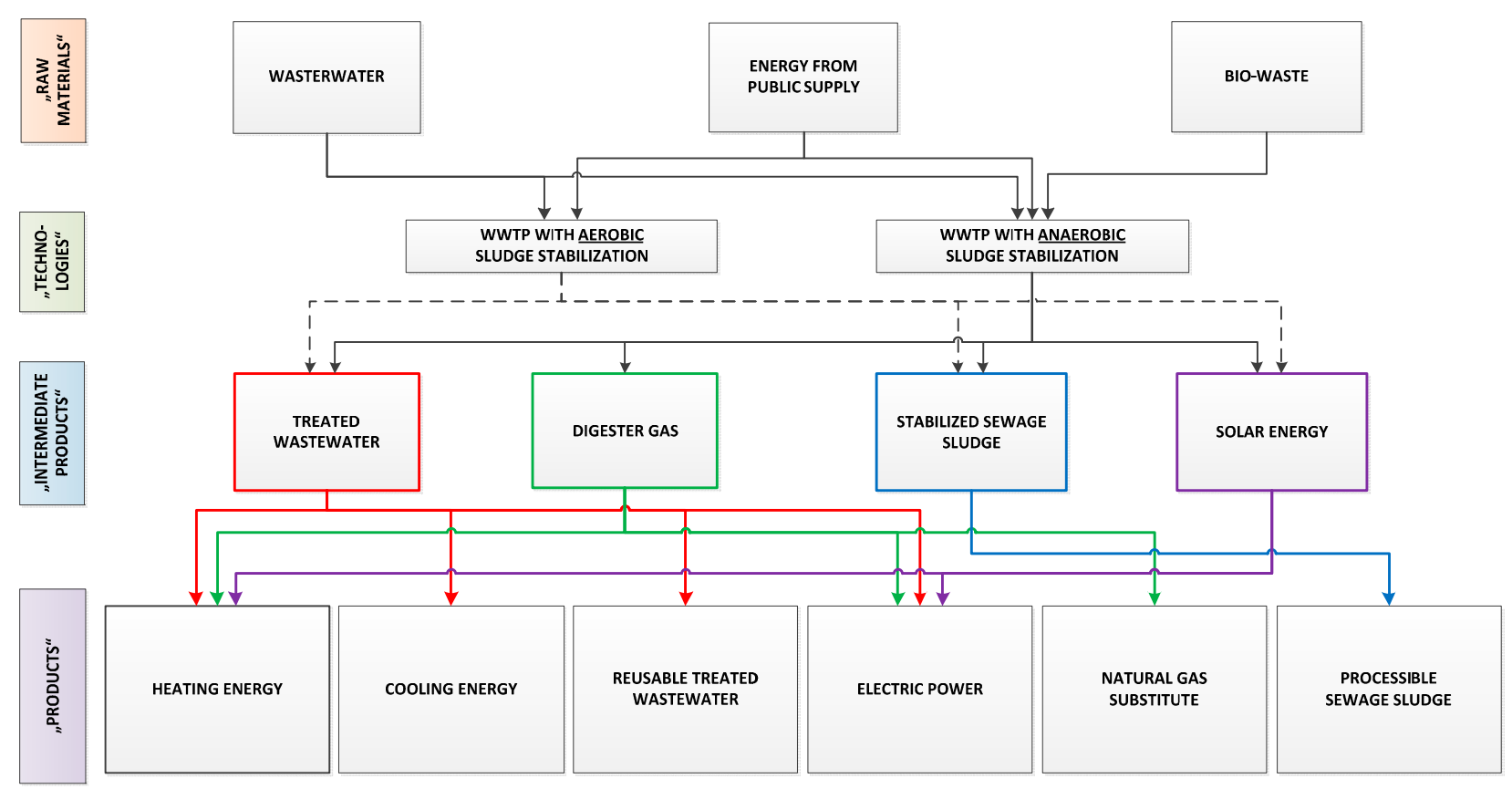

Figure 1. Energy and resource consumption and generation at wastewater treatment plants (WWTPs) [22].

Establishing WWTPs as nodes in existing energy networks can contribute to saving resources, reducing waste streams and thus making regional energy systems more feasible [23]. Therefore, the following aspects have to be considered [22]: Top priority has to be set to energetic optimization of the WWTP via efficient use of electrical and thermal energy, increase of the energy generation output at the site and internal re-use of energy and resources. Surplus energy and resources shall be purposefully re-used in the vicinity of the WWTP after identification of current and future energy demands in coordination with all relevant stakeholders (e.g., municipality, spatial planners and existing energy suppliers). Depending on the location of the WWTP and the presence of potential energy consumers, a utilization for agricultural and forestry purposes, for climatization of buildings, or for mobility purposes as a substitute for natural gas come into consideration as potential fields of application [24]. Furthermore, the optimization of internal and external energy and resource flows represents an important goal. This calls for the identification of the most appropriate potential application of the present energy and resources from an economic and environmental point of view taking the spatial context of a WWTP into account. 
Several research efforts have identified wastewater as a significant energy source [7,25]. The recovery of wastewater energy from WWTPs can be considered an environmentally friendly, approved and economically competitive technology as numerous feasibility studies and realized wastewater heat recovery systems throughout Europe, for instance in Switzerland [26,27], Scandinavia [28,29] and Germany [30,31], have demonstrated. In Austria, wastewater heat recovery is to date not as prevalent as in the above-mentioned countries, although some projects have been realized already [25].

In Switzerland, cantons and municipalities can draw on cantonal and municipal energy structure plans that aim at analyzing the energy supply and identifying strategies to optimize the use of localized waste heat and renewable energy sources [32]. Guidances on such energy structure plans prioritize the use of energy in a ranking list where the top priority is given to localized high-grade waste heat followed by localized low-grade waste and ambient heat (e.g., from WWTPs) [4]. Municipal energy structure plans prove to be powerful instruments as several realized projects for the use of thermal energy recovered from wastewater have been initiated.

Taking into account spatial contexts, this paper presents a methodology to estimate thermal energy resource potentials of wastewater treatment plants (WWTPs), which was carried out in the framework of the research project "Wastewater Energy-Integration of Wastewater Infrastructure into Regional Energy Supply Concepts". The methodology is demonstrated on the Austrian case, but is transferable to all countries with a comparable database, e.g., the whole European Union. The methodology is based on the fact that spatial analysis of energy efficiency, supply and resource potentials leads to a better decision base for energy planning [33,34]. With reference to their spatial contexts, different types of WWTPs can be distinguished by means of distance between the energy source (WWTP) and potential energy sinks in the surroundings. Subsequent to an overview of the Austrian WWTP inventory, the method for the spatial analysis is described in the next section. Based on these findings, thermal (and electric) energy potentials are estimated for Austrian WWTPs and evaluated with the Sustainable Process Index (SPI) depicting the ecological footprint, $\mathrm{CO}_{2}$-life-cycle-emissions and the global warming potential (GWP). The results are discussed concerning the potential contribution of WWTP energy generation to climate protection targets, followed by a brief conclusion section addressing the drafting of local and regional energy strategies as well as energy policy making.

\section{Materials and Methods}

\subsection{Status Quo of Austrian WWTPs}

According to the 2014 situation report on the disposal of urban waste water and sludge the current treatment capacity of the Austrian WWTPs amounts to 21.6 million population equivalents (PE) provided by 1842 WWTPs by the reporting date of 31 December 2012 [35]. About two thirds of the WWTPs (1204) have a treatment capacity lower than 2000 PE representing about $2.1 \%$ of the current treatment capacity with a total of 462,087 PE. 638 WWTPs with a treatment capacity higher than 2000 PE comprise $97.9 \%$ of the Austrian treatment capacity (21.15 million PE).

Data about the latter WWTPs with a reporting obligation according to Section 2 paragraph 1 No. 2 of the emission register regulation surface water [36] are available from the central emission register which serves as a basis for the fulfillment of EU Community law reporting requirements, in particular according 
to the Council Directive 91/271/EEC concerning urban waste water treatment. For the analysis carried out in the research project "Wastewater Energy - Integration of Wastewater Infrastructure into Regional Energy Supply Concepts" data about the current Austrian WWTPs were provided by the Environment Agency Austria on behalf of the Austrian Federal Ministry of Agriculture and Forestry, Environment and Water Management [37] comprising a set of 632 municipal WWTPs.

In principle, communal WWTPs with a treatment capacity above $5000 \mathrm{PE}$ are of potential interest in the presented research work due to the fact that these facilities have de-nitrification processes as a result of legal regulations [38]. However, the relevance of energetic optimization and utilization may stand in the background against operational safety in the case of WWTPs with lower treatment capacities. In the framework of the WWTP benchmarking presented at the annual conferences of the "Kanal-und Kläranlagennachbarschaften" (sewer and wastewater treatment plants provider network), WWTPs with higher treatment capacities are differentiated in WWTPs under and above 50,000 PE, whereas the biennial situation report about the treatment of communal wastewater distinguishes between WWTPs with a treatment capacity under and above 150,000 PE. Therefore, in the framework of this research the four size categories illustrated in Table 1 were chosen, which appear suitable for the project purposes.

Table 1. Austrian communal WWTP inventory according to wastewater related criteria $[37,39]$.

\begin{tabular}{cccc}
\hline $\begin{array}{c}\text { Size Category } \\
(\text { PE) }\end{array}$ & $\begin{array}{c}\text { Amount of WWTPs with } \\
\text { Aerobic Sludge Stabilization }\end{array}$ & $\begin{array}{c}\text { Amount of WWTPs with } \\
\text { Anaerobic Sludge Stabilization }\end{array}$ & $\begin{array}{c}\text { Total Amount of } \\
\text { WWTPs }\end{array}$ \\
\hline $2000-5000$ & 246 & 3 & 249 \\
$5001-50,000$ & 216 & 104 & 320 \\
$50,001-150,000$ & 10 & 37 & 47 \\
$>150,000$ & 2 & 14 & 16 \\
TOTAL & $\mathbf{4 7 4}$ & $\mathbf{1 5 8}$ & $\mathbf{6 3 2}$ \\
\hline
\end{tabular}

\subsection{Spatial Contexts of WWTPS}

With regard to the integration of WWTPs in regional and communal energy concepts, wastewater related criteria (Table 1) as treatment capacity (four categories) and kind of sludge treatment (aerobic and anaerobic sludge stabilization) will be complemented with a spatial planning view. Taking into account spatial contexts allows for an estimation of viable potentials, as technical potentials are supplemented with information on available energy consumers in the vicinity of a WWTP.

Attachment 3 of the Austrian situation report 2014 on the disposal of urban waste water and sludge includes a map depicting all WWTPs with a treatment capacity of more than 2000 PE that is also online available at the website of the Austrian Federal Ministry of Agriculture and Forestry, Environment and Water Management [40]. The map is complemented with a dataset including position coordinates of WWTPs, treatment capacity and annual wastewater amount [37].

Furthermore, the latest available land cover dataset of the CORINE (Coordination of information on the environment) program of the European Commission [41] was used for the spatial analysis. In the framework of the CORINE program consistent localized geographical information on the land cover for most areas of Europe is provided in 44 land cover classes [42]. For the spatial analysis in this research three classes of artificial surfaces (1) continuous urban fabric (1.1.1); (2) discontinuous urban fabric (1.1.2) and (3) industrial or commercial units (1.2.1) were selected, that are defined as follows: 
- "continuous urban fabric" is mostly characterized by built structures and transport infrastructure with little coverage of vegetation and bare soils;

- "discontinuous urban fabric" includes both built structures as well as vegetated areas and bare soil with discontinuous, but significant shares on the land coverage;

- "industrial or commercial units" are defined as built environments with a small share of vegetated areas.

The above-mentioned datasets were transferred into a Geographical Information System (GIS) and intersected with each other. The vicinity of the Austrian WWTPs was analyzed in circular areas with several radii determining the maximum distance between heat source and heat sink for the configuration of an economical district heating system applying thermal energy from wastewater. The three distance classes of 0-150 m (location of the WWTP within the settlement, 150-1000 m (near to the settlement) and longer than $1000 \mathrm{~m}$ (far from the settlement) were derived from [43,44].

Dependent on the present land cover classes in the vicinity of a WWTP (directly adjacent to the site within a radius of $150 \mathrm{~m}$, and near to the site within a radius of $1000 \mathrm{~m}$ ) three types of spatial contexts for the Austrian WWTPs were defined as illustrated in Figures 2-4:

(1) WWTPs "within the settlement" are located in a distance of up to $150 \mathrm{~m}$ to the nearest spot of at least one of the considered land cover classes, which cover an area of at least 25 hectares within the $1000 \mathrm{~m}$ radius around the WWTP.

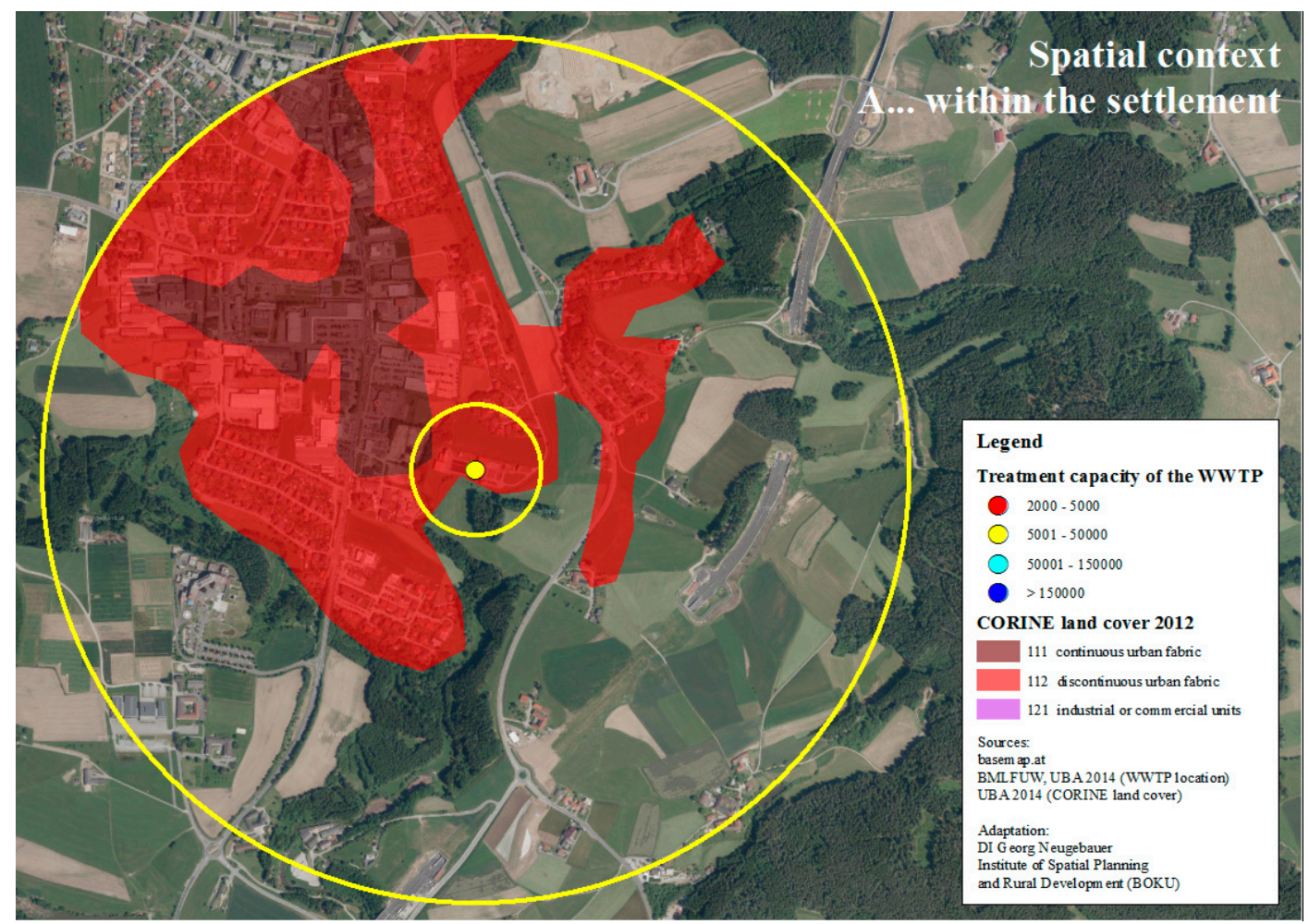

Figure 2. Example of a WWTP in size category 1 within the settlement area.

(2) WWTPs situated "near to settlement" are characterized by an essential share of the circular area covered by at least one of the considered land cover classes with a minimum amount of 25 hectares in a radius between $150 \mathrm{~m}$ and $1000 \mathrm{~m}$ around the WWTP. 


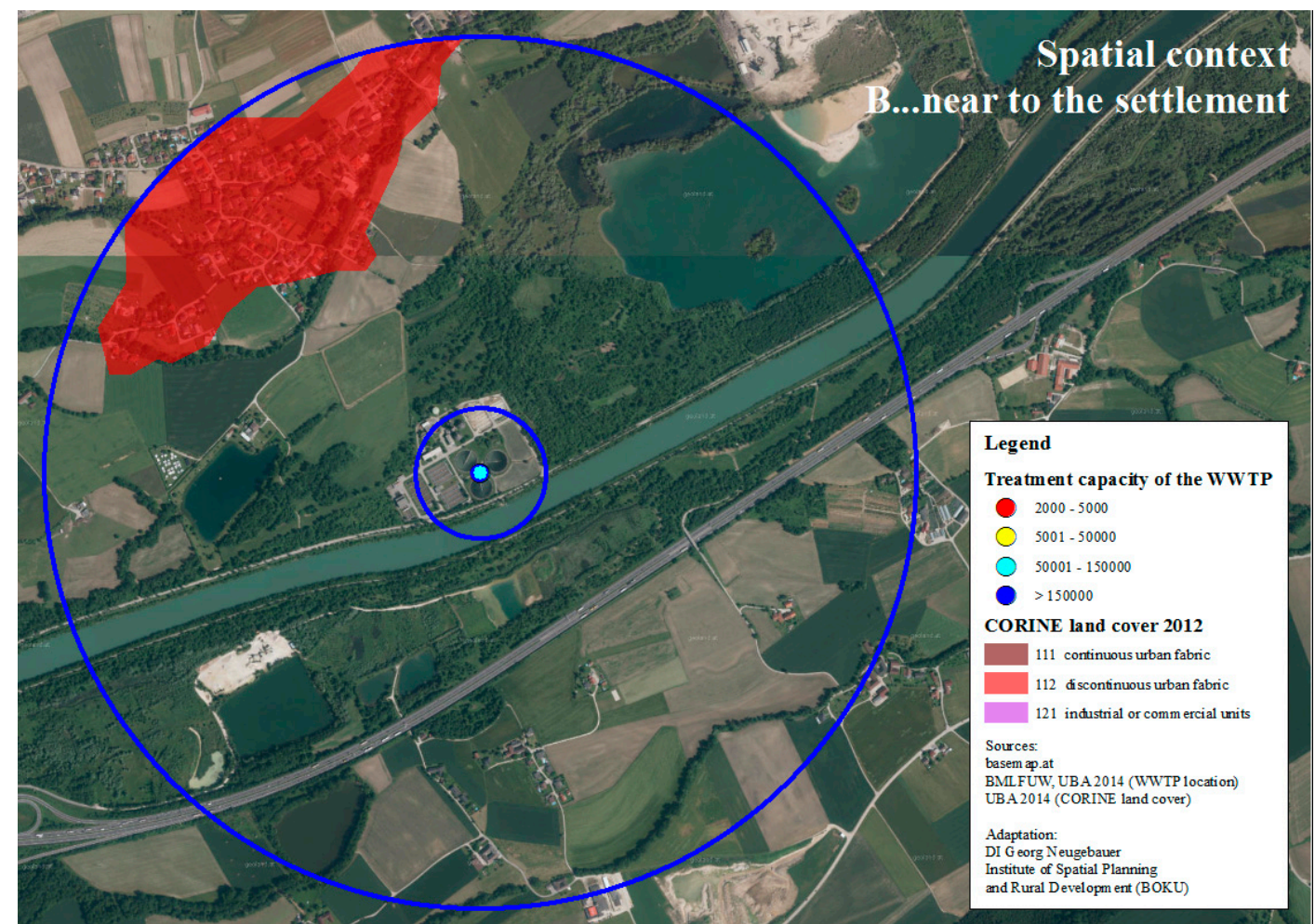

Figure 3. Example of a WWTP in size category 3 near to the settlement area.

(3) WWTPs situated "far from the settlement" do not contain significant shares of areas in the considered land cover categories within the $1000 \mathrm{~m}$ radius around the WWTP site.

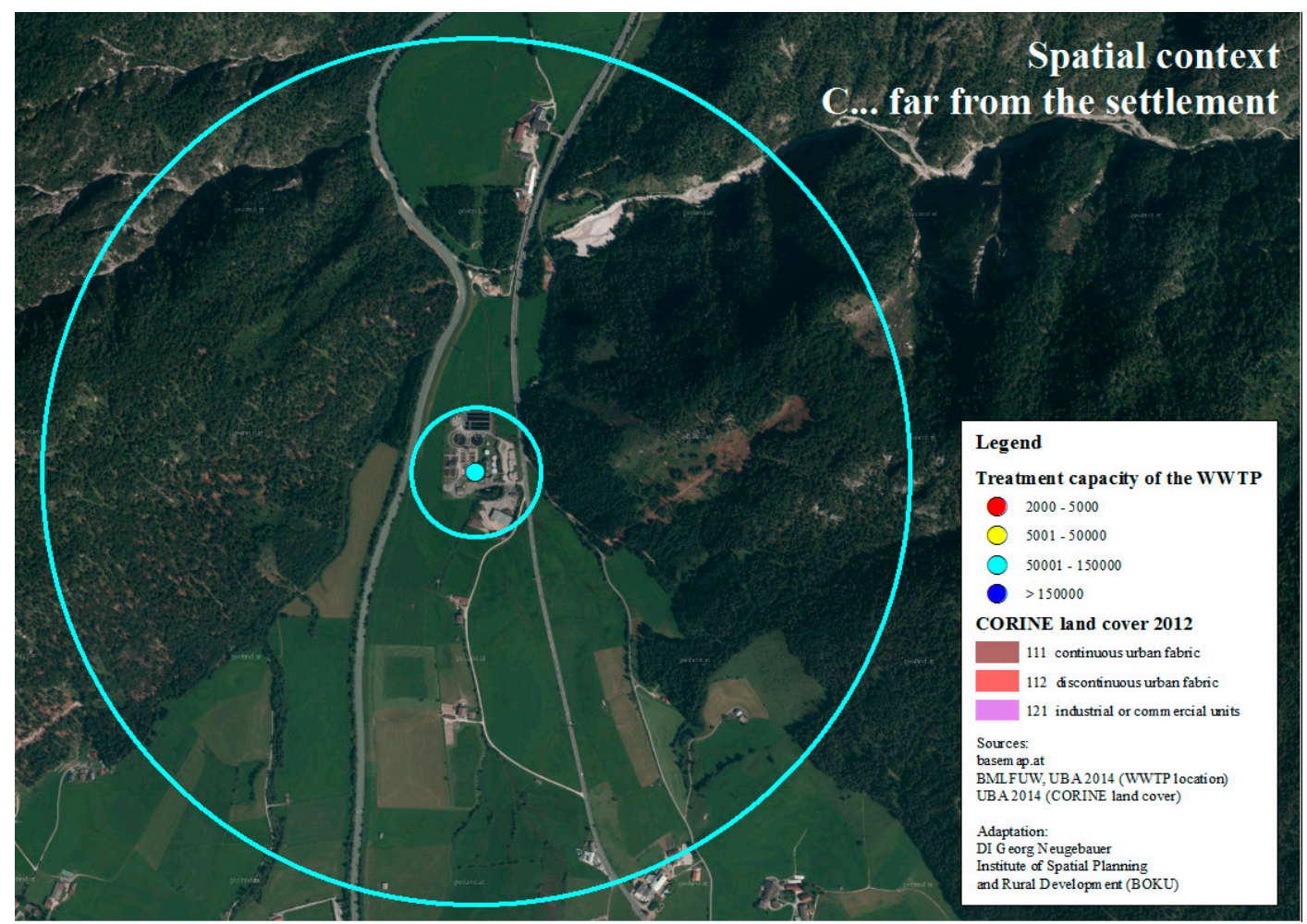

Figure 4. Example of a WWTP in size category 2 far from the settlement area. 
The term "settlement area" includes not only the residential function but, moreover, considers all spatial functions within the several categories of building land, e.g., manufacturing companies, trade and services as well as public institutions. In this way settlement structures with mixed functions are taken into account that may show load profiles more favorable to the supply with district heating systems than exclusively residential areas. This is due to the fact that very likely mixed function areas show a more continuous heat demand compared to mono-functional land uses. This is a substantial precondition for an efficient operation of the thermal energy extraction. Depending on the spatial context about 4500 to 6000 full load hours for heating per year may be required, whereas pure residential areas provide for about 1500-2200 full load hours per year for a district heating system [44-47]. Therefore, taking the spatial structure of potential supply areas into account allows for an assumption of at least 4.500 full load hours. This can be expected for areas that do not only combine residential areas with office space, but include infrastructures like hospitals, indoor swimming pools and other commercial and agricultural uses like glasshouses, drying of agricultural and forest products etc.

The results of the analysis of the spatial contexts of WWTPs throughout Austria are depicted in Table 2. About two thirds of all Austrian WWTPs are situated in close proximity to settlement structures (238 WWTPs within settlement areas and 182 near to settlement areas), whereas one third of the WWTPs are located far from settlement structures.

Table 2. Types of Austrian communal WWTPs by the reporting date of 31 December 2013 according to wastewater related and spatial criteria [37,39].

\begin{tabular}{|c|c|c|c|c|c|c|c|c|c|}
\hline \multirow[t]{2}{*}{ Sludge Treatment } & & \multirow[t]{2}{*}{ Size Category } & \multicolumn{6}{|c|}{ Spatial Context } & \multirow[b]{2}{*}{ Sum } \\
\hline & & & $\mathrm{A}$ & $\begin{array}{l}\text { within the } \\
\text { settlement }\end{array}$ & B & $\begin{array}{l}\text { near to the } \\
\text { settlement }\end{array}$ & $\mathrm{C}$ & $\begin{array}{l}\text { far from the } \\
\text { settlement }\end{array}$ & \\
\hline \multirow{5}{*}{$\begin{array}{l}\text { Aerobic sludge } \\
\text { stabilization }\end{array}$} & 0 & 2000-5000 PE & & 77 & & 74 & & 95 & 246 \\
\hline & 1 & 5001-50,000 PE & & 74 & & 74 & & 68 & 216 \\
\hline & 2 & $50,001-150,000 \mathrm{PE}$ & & 3 & & 3 & & 4 & 10 \\
\hline & 3 & $>150,000 \mathrm{PE}$ & & 2 & & 0 & & 0 & 2 \\
\hline & & Sum & & 156 & & 151 & & 167 & 474 \\
\hline \multirow{6}{*}{$\begin{array}{l}\text { Anaerobic sludge } \\
\text { stabilization }\end{array}$} & 0 & $2000-5000 \mathrm{PE}$ & & 1 & & 0 & & 2 & 3 \\
\hline & 1 & 5001-50,000 PE & & 50 & & 24 & & 30 & 104 \\
\hline & 2 & $50,001-150,000 \mathrm{PE}$ & & 22 & & 5 & & 10 & 37 \\
\hline & 3 & $>150,000 \mathrm{PE}$ & & 9 & & 2 & & 3 & 14 \\
\hline & & Sum & & 82 & & 31 & & 45 & 158 \\
\hline & & TOTAL & & 238 & & 182 & & 212 & 632 \\
\hline
\end{tabular}

\subsection{Classification of WWTP Energy Potentials}

After classifying the spatial context of WWTPs, the suitability of WWTPs for energy supply has to be determined taking not only the spatial context, but also the size of the plant into account. The bigger the treatment capacity is, the longer the distance between the WWTP and the first energy consumer can be from an economic and resource efficiency point of view. The four size categories and the three categories of spatial context can be interlinked in a matrix according to Table 3, resulting in three categories of suitability, marked according to the traffic light system: 
- "not suitable" (red): small WWTPs with a large distance to consumers;

- "conditionally suitable" (yellow): small to medium sized WWTPs where a case-by-case examination is needed to survey the potentials in detail;

- "suitable" (green): medium to large sized WWTPs, which very likely can be utilized for district heat supply.

The classification takes the size distribution of the WWTPs into account, e.g., WWTPs in the size category 1 (5000-50,000 PE) situated within settlement areas are considered as suitable because the majority of these WWTPs has a treatment capacity of more than 15,000 PE.

Table 3. Suitability matrix of WWTPs for district heating.

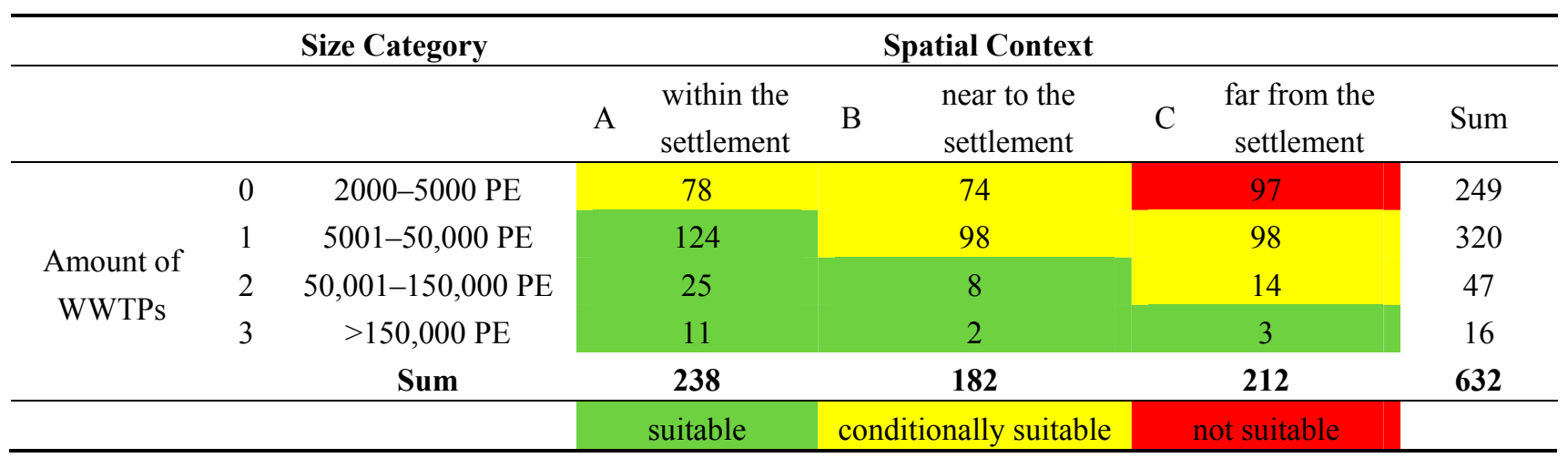

Concerning potential electricity supply, the spatial context is not so important: First, only a certain share of the WWTPs' electricity demand can be provided without co-generation of biogas from other sources at the WWTP. With biogas co-generation from other substrates it is possible to generate more electricity as the WWTPs self-demand [18,19], but the question is where these substrates might originate in the amount needed for a substantial energy supply. Such potentials are case-specific and cannot be included in such a country-wide analysis. Second, the thermal energy generated in a combined heat and power cycle can be used to cover the internal heat demand of the WWTP so that external heat supply is not necessarily feasible without co-generation.

\subsection{Environmental LCIA}

Life Cycle Assessment (LCA) has become an integral part of planning processes in industry as well as for energy and infrastructure systems [48]. It is an investigative tool to analyze environmental impacts of human activities and products, from raw material mining, through production and use, to waste management [49]. Even if LCAs not always receive appropriate attention, LCA is becoming more and more incorporated in Research and Development projects, contribute to reducing the environmental impacts of technologies and acting as a helpful hand finding environmental friendly solutions [50,51]. An essential part of any LCA, which evaluates the pressure on the environment executed by the life cycle of a product or service, is the Life Cycle Impact Assessment (LCIA) [52]. The Sustainable Process Index (SPI) is a LCIA method evaluating environmental impacts caused by individual processes steps in a life cycle. This method is a member of the ecological footprint family. Furthermore, it is compatible with the procedure of the life cycle analysis described in the EN ISO 14040 standard [53]. 
The SPI calculates the ecological footprint as the cumulative area to embed the whole life cycle of an industrial process sustainably into the biosphere. It describes relevant ecological pressures of a process including all emerging emissions, the pre-chain and product usage [54].

Material and energy flows of a product or service, which are extracted from and dissipated to the ecosphere, are compared to natural flows [55]. In detail, the areas shown in Figure 5 comprise the overall footprint.

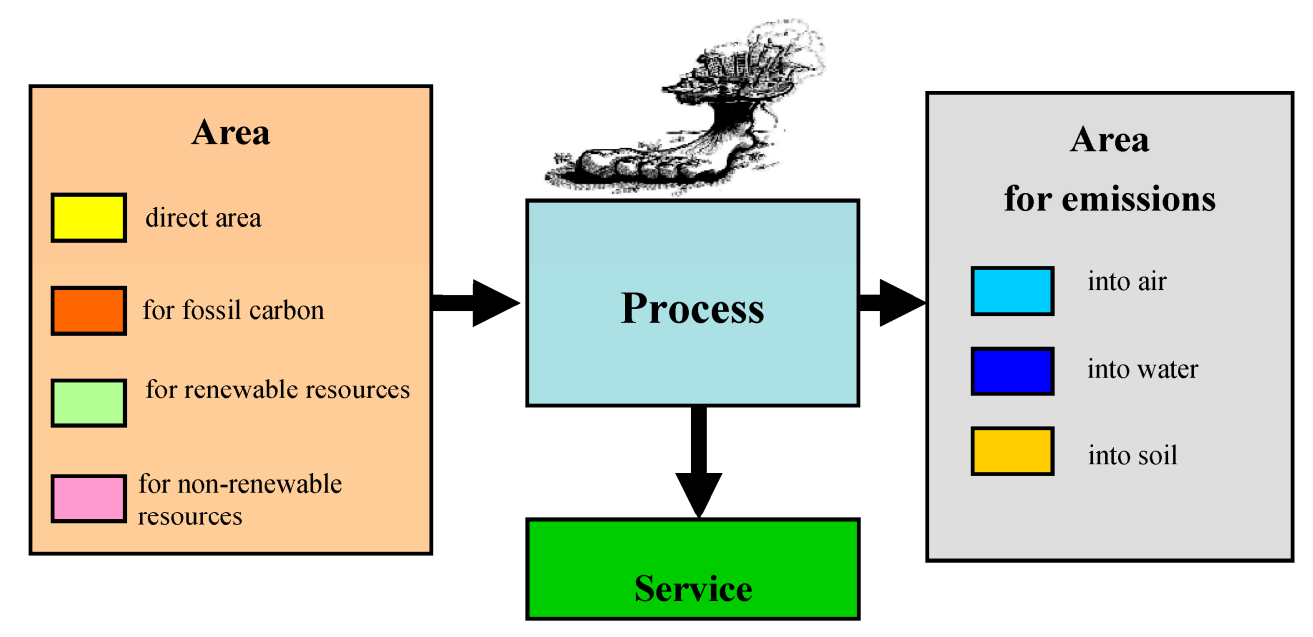

Figure 5. Sustainable Process Index (SPI) calculation, material and energy flows of a process (SPIonWeb [56]).

The SPI method has been implemented in the open access tool SPIonWeb, freely available on http://spionweb.tugraz.at/. With this tool it is possible to create whole life cycles by building up process chains, which can be updated and improved easily. Only a web browser is needed to sign up and use SPIonWeb. It is independent from any operating system. As results, the user gets the SPI-footprint, $\mathrm{CO}_{2}$-life-cycle-emissions and the global warming potential (GWP) of the whole life cycle.

SPIonWeb compares different technologies. For this paper and the current research project, different heat generating technologies were compared with each other. Using a heat exchanger and heat pump, three different scenarios were generated. In Figure 6 the ecological pressure for $1 \mathrm{kWh}$ generated thermal energy is presented using a EU electricity mix, the average Austrian mix and a renewable based mix (PV power $37.4 \%$, wind power $22.3 \%$, hydro power $19.5 \%$, biomass fired power $6.2 \%$ and other renewable resources $14.6 \%$ ) as an input for a heat pump. These three scenarios were compared to the combustion of wood chips and to heat provided with natural gas as fossil base representative.

Obviously, the used electricity mix to run the heat pump has a strong influence on the ecological pressure. The heat pump driven by the EU mix $\left(72.9 \mathrm{~m}^{2} / \mathrm{kWh}\right)$ generates more than the double ecological footprint compared to one driven by the Austrian electricity mix $\left(34.8 \mathrm{~m}^{2} / \mathrm{kWh}\right)$. The footprint executed by the heat pump supplied by the EU electricity mix is even a bit higher than the footprint for thermal energy from burning natural gas $\left(72.5 \mathrm{~m}^{2} / \mathrm{kWh}\right)$. A more sustainable option is offered by scenario three, a heat pump supplied by electricity from renewable resources only $\left(1.1 \mathrm{~m}^{2} / \mathrm{kWh}\right)$. Another alternative could be the heat from the combustion of wood chips which causes a footprint of $9 \mathrm{~m}^{2} / \mathrm{kWh}$ in Austria, which has a lower footprint than the heat pump using the current Austrian electricity mix but still considerably higher than a heat pump driven renewable electricity combining solar, wind and hydropower. 


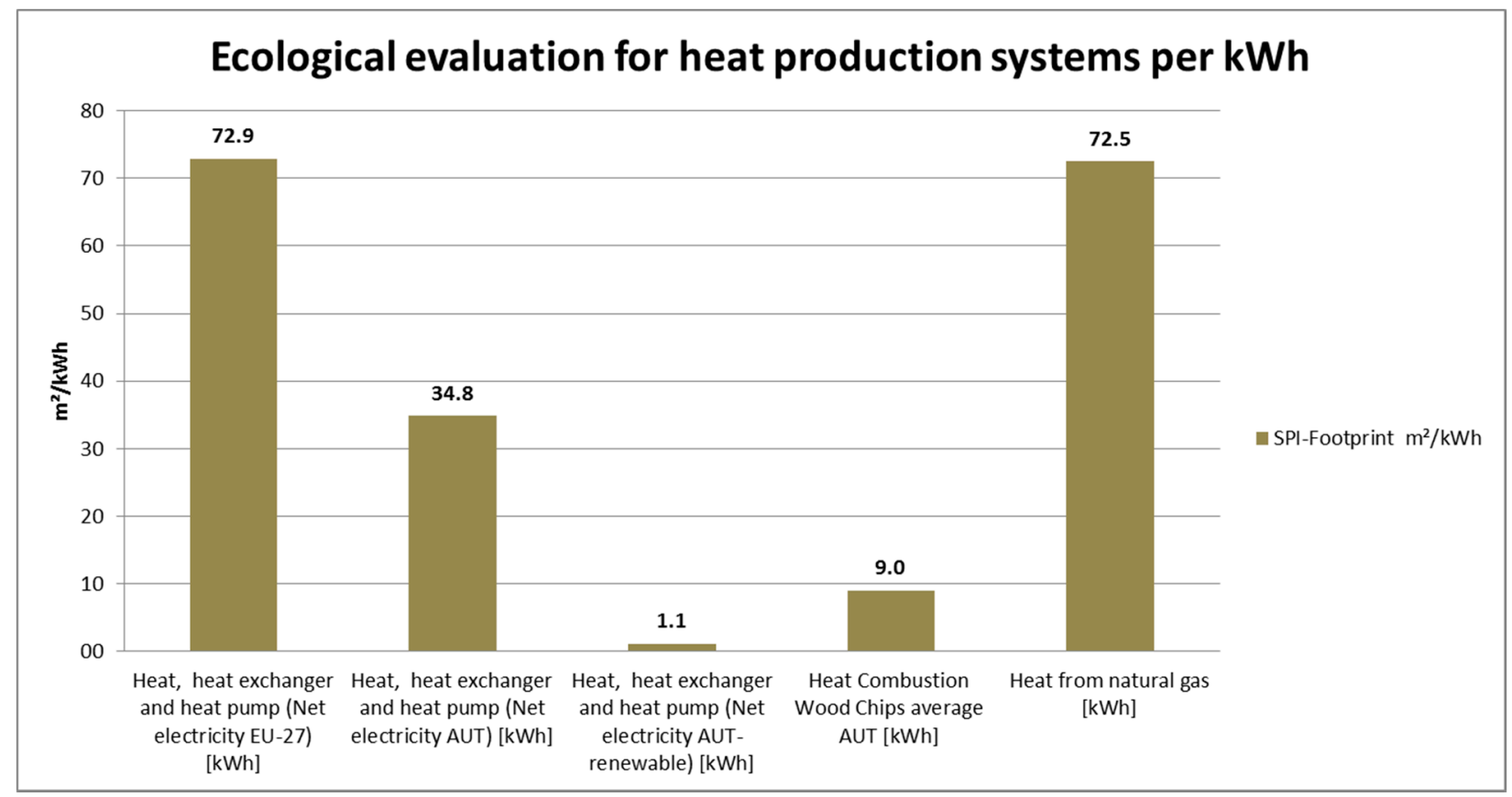

Figure 6. SPI-Footprint for heat production systems per kWh (based on SPIonWeb [56]).

Additional to the ecological footprint, the $\mathrm{CO}_{2}$ emissions and the GWP were calculated. The results are illustrated in Figure 7.

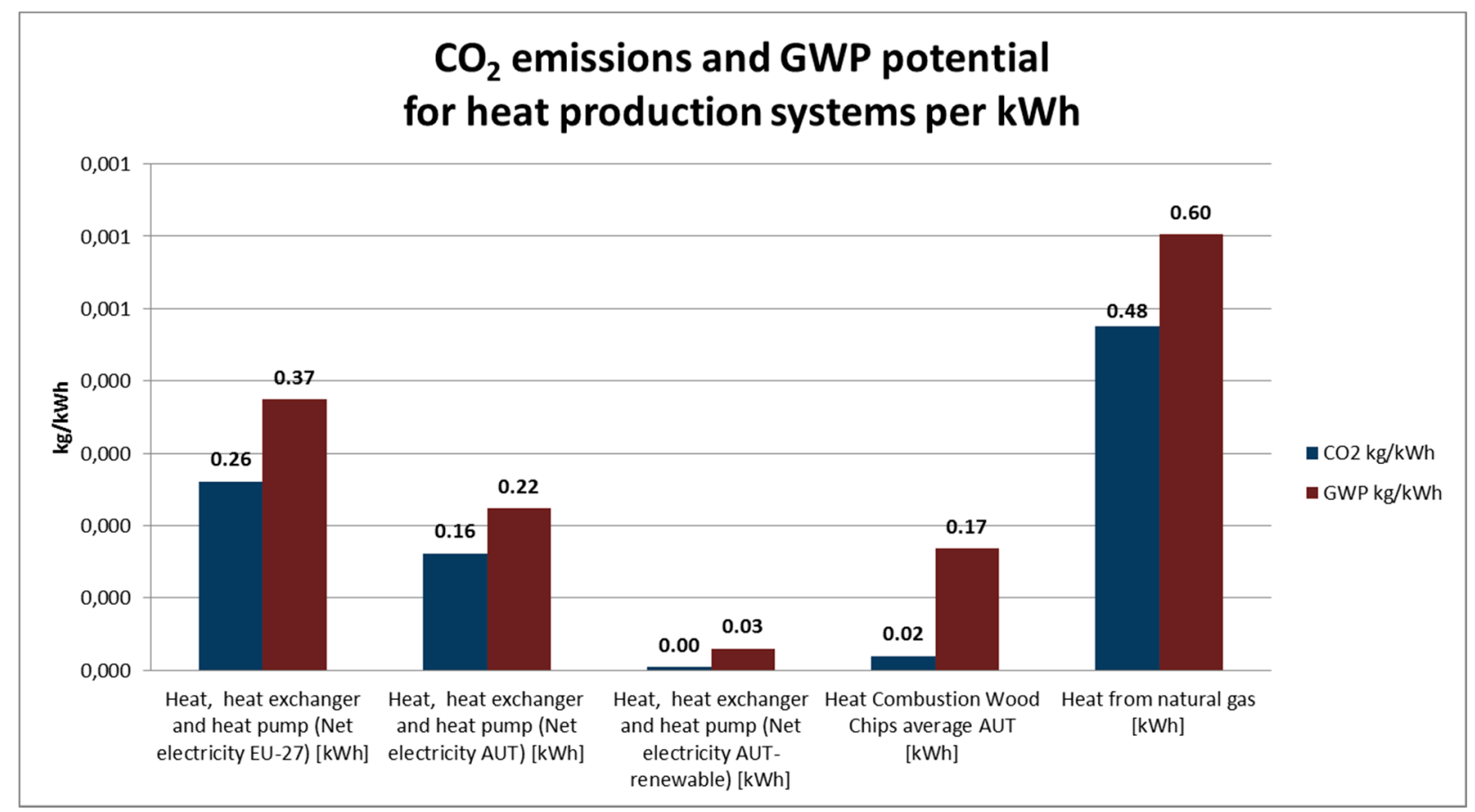

Figure 7. $\mathrm{CO}_{2}$ emissions and GWP potential for heat production systems per $\mathrm{kWh}$ (based on SPIonWeb [56]).

Looking at the $\mathrm{CO}_{2}$ emissions and the GWP generated by the various heat generation systems, heat from gas has the highest value in both cases $(0.48 \mathrm{~kg} / \mathrm{kWh} \mathrm{CO} 2$ and $0.60 \mathrm{~kg} / \mathrm{kWh} \mathrm{GWP})$. Compared to the footprint, the discrepancy between the heat pump scenarios is not as pronounced, still using a

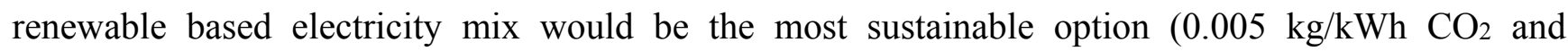


$0.030 \mathrm{~kg} / \mathrm{kWh}$ GWP). Burning wood chips for the generation of thermal energy $\left(0.02 \mathrm{~kg} / \mathrm{kWh} \mathrm{CO}_{2}\right.$ and $0.017 \mathrm{~kg} / \mathrm{kWh}$ GWP) would again produce $\mathrm{CO}_{2}$ emissions and a GWP with a value between the heat pumps driven by the Austrian $(0.16 \mathrm{~kg} / \mathrm{kWh} \mathrm{CO} 2$ and $0.22 \mathrm{~kg} / \mathrm{kWh}$ GWP) and the renewable electricity mix. The EU mix operated heat pump is emitting $0.26 \mathrm{~kg} / \mathrm{kWh} \mathrm{CO}_{2}$ and has a GWP of $0.37 \mathrm{~kg} / \mathrm{kWh}$, implying the highest ecological pressure related to the heat pumps using more renewable based electricity mixes.

According to these results two scenarios for the WWTP heat recovery with heat pumps are calculated: (1) the Austrian average electricity mix; and (2) a renewable based electricity mix. These scenarios are compared to a scenario where the full heat supply (room heating and warm water) is provided by fossil natural gas (scenario 3). With these scenarios the impact of a possible WWTP energy recovery program on the Austrian climate policy targets is estimated under the assumption that all potentials can be exploited. This assumption is justified by the method of the spatial context analysis, as only real land uses are considered as potential energy sinks.

\section{Results and Discussion}

This section describes the estimation of the thermal energy potential from wastewater and the thermal (and electric) energy potential recovered from digester gas production. By means of a Life Cycle Impact Assessment (LCIA) applying the Sustainable Process Index (SPI) the potential environmental impacts are evaluated and discussed.

\subsection{Thermal Energy Potential Recovered from Wastewater}

For the estimation of the theoretical potential of thermal energy supply from wastewater effluent, the available amount of treated wastewater and the temperature level represent essential determining factors according to Formula (1). The thermal extraction output from wastewater $\left(P_{W W}\right)$ can be computed from the product of wastewater volume flow rate $\left(V_{W W}\right)$, specific thermal capacity of wastewater $(c)$ and the temperature difference $(\Delta \mathrm{T})$.

$$
P_{W W}=V_{W W} \times c \times \Delta \mathrm{T}
$$

In Austria, the hourly dry weather discharge can be estimated with a 30\% reduction of the wet weather flow. The annual runoff of about 1148 million cubic meters for all 632 Austrian WWTPs with a treatment capacity more than $2000 \mathrm{PE}$ results in an hourly dry weather discharge of about $91,760 \mathrm{~m}^{3}$.

Furthermore, the estimation of the thermal energy potential is based on the following assumptions [25]:

- The specific thermal capacity of wastewater is calculated with the appropriate value of water $\left(1.16 \mathrm{kWh} / \mathrm{m}^{3} \times \mathrm{K}\right)$.

- The average wastewater temperature in the heating period is estimated at $10^{\circ} \mathrm{C}$.

- The wastewater in the effluent will be cooled down to $5{ }^{\circ} \mathrm{C}$, so that $5 \mathrm{~K}$ can be extracted.

Under these assumptions, a total heat capacity of about $533 \mathrm{MW}$ can be provided from wastewater in the several types of WWTPs as depicted in Table 3, amounting in about $700 \mathrm{MW}$ of total heat capacity including the electricity demand of the heat pumps with a performance factor of 4 according to Formula (2).

$$
P_{H P}=P_{W W} \times C O P /(C O P-1)
$$


About $72 \%$ of the heat capacity can be provided at WWTPs which are in the category "suitable" for the provision of thermal energy for external utilization. Further $25 \%$ of the thermal energy potential can be generated at WWTPs that appear at least to be "conditionally suitable". It should be mentioned, that for an optimal use of the heat pumps bivalent systems should be applied so that the heat pumps can provide basic loads, and peak loads can be covered from an additional system, e.g., biomass wood chips.

Table 4. Heat capacity (MW) and thermal energy (GWh/a) in case of cooling down the wastewater effluent by $5 \mathrm{~K}$ and 4500 full load hours.

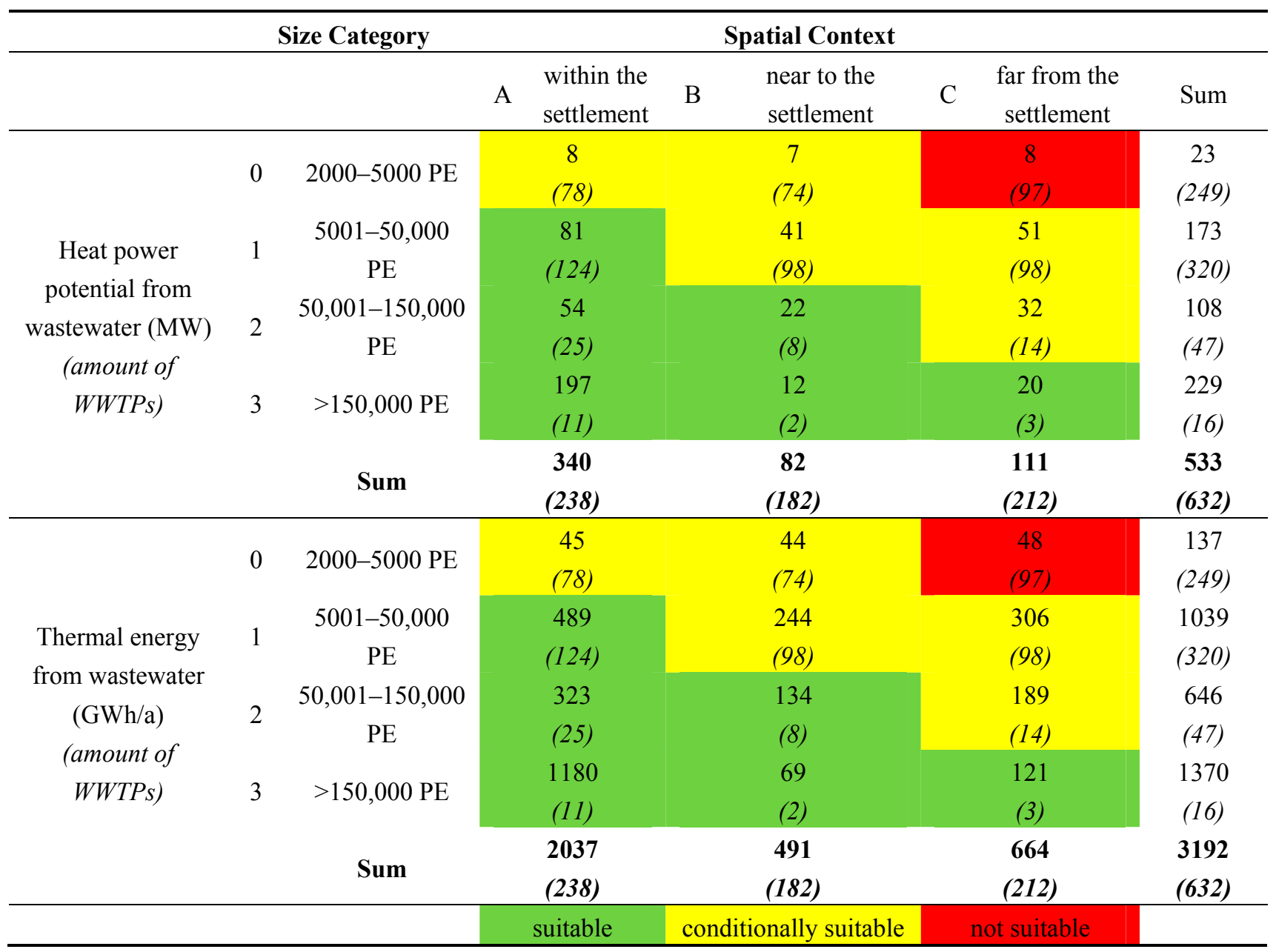

Table 3 illustrates the thermal energy potential from wastewater under the above described assumptions concerning the amount of wastewater, degree of cooling and heat pump calculated with 4500 full load hours in multi-functional contexts. Regardless of dual-system modes, the thermal energy potential heat pumps at suitable or conditionally suitable WWTP locations can be estimated with an amount of $3144 \mathrm{GWh} / \mathrm{a}$. 


\subsection{Thermal Energy Potential Recovered from Digester Gas Production}

WWTPs equipped with digesters offer digester gas as an additional source of energy for heat generation via gas burners or CHPs. In the case of CHP beside thermal energy also electrical energy can be provided. In this section, thermal energy generation applying CHP is assumed. Therefore, an overview on the electrical energy potential recovered from digester gas generation is presented for the sake of completeness.

The thermal energy supply $\left(E S_{t h}\right)$ from digester gas can be estimated according to Formula (3) as the product of the actual load entering the WWTP $(L E)$ in population equivalent (PE) and the thermal biogas energy factor $\left(B E F_{t h}\right)$. For Austrian WWTPs, reported thermal biogas energy factors range from 20 to $40 \mathrm{kWh} / \mathrm{PE} \times \mathrm{a}[16]$.

$$
E S_{t h}=L E \times B E F_{t h}
$$

Assuming an average energy supply of $30 \mathrm{kWh}$ per population equivalent and year, a thermal potential of $231 \mathrm{GWh} / \mathrm{a}$ arises from the above-mentioned 158 WWTPs [39] depicted in Table 4.

Table 5. Estimation of thermal and electric energy supply potential from digester gas production (in $\mathrm{MWh} / \mathrm{a}$ ).

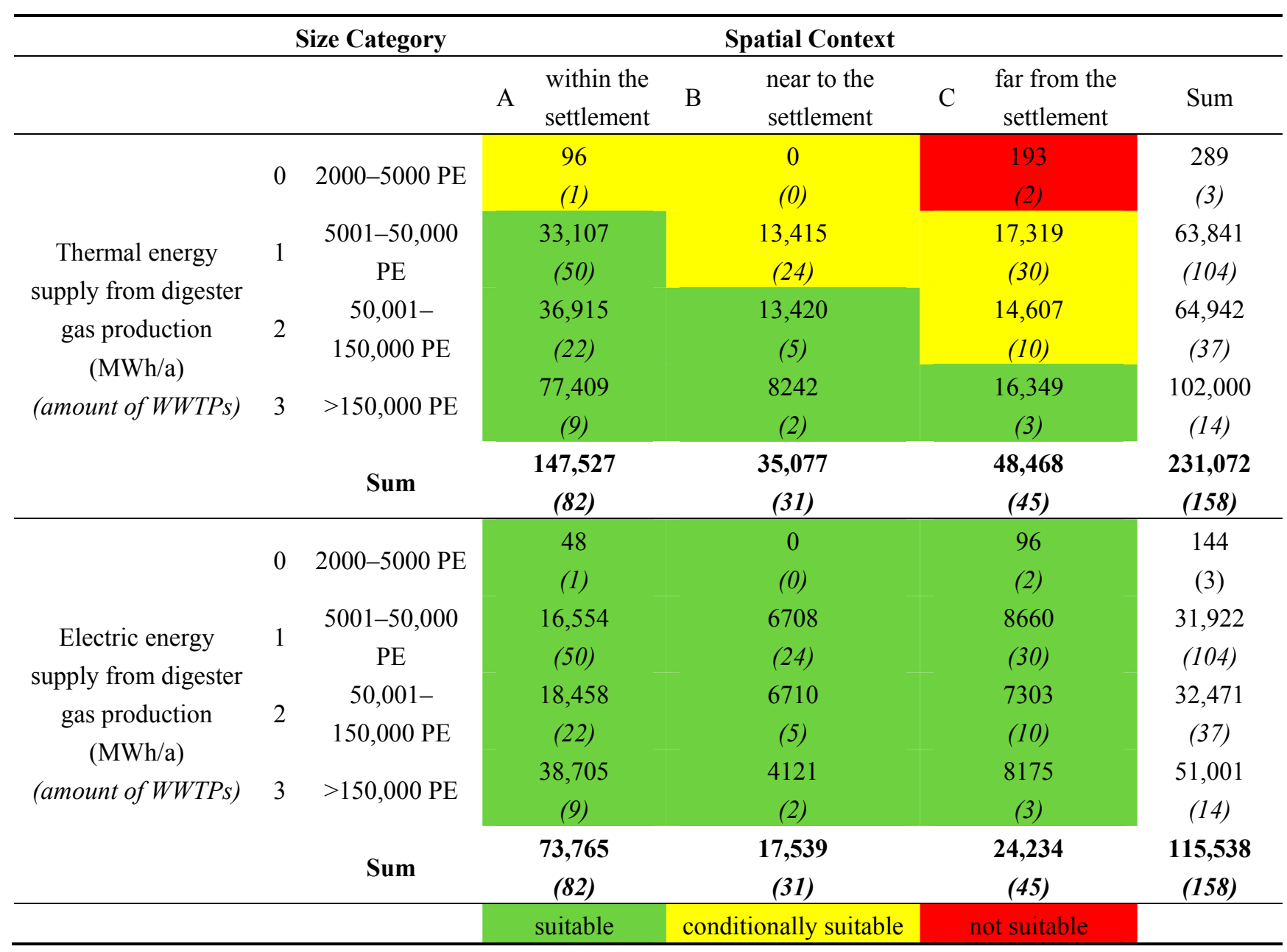


The annual amount of electricity generated from digester gas can be estimated according to Formula (4) as the product of the actual load entering the WWTP $(L E)$ in PE and the electric biogas energy factor $\left(B E F_{e l}\right)$. For Austrian WWTPs, reported electric biogas energy factors range from 10 to $20 \mathrm{kWh} / \mathrm{PE} \times \mathrm{a}$ [16].

$$
E S_{e l}=L E \times B E F_{e l}
$$

Assuming an average energy supply of $15 \mathrm{kWh}$ per population equivalent and year, for the 158 Austrian municipal WWTPs equipped with digester towers [39], about $115.5 \mathrm{GWh} / \mathrm{a}$ electricity may be provided to cover energy consumption at the WWTPs themselves.

\subsection{Summary of the Thermal Energy Resource Potentials}

From the potential calculations presented above can be derived, that the heat potential at WWTPs from digester gas and extraction from the wastewater effluent can be estimated in the order of $3375 \mathrm{GWh} / \mathrm{a}$ and the potential for power generation in a dimension of $115.5 \mathrm{GWh} / \mathrm{a}$. The estimations reveal a considerable heat surplus as the main, or even only energy resource potential that can be provided for external uses. To express the magnitude, this figure can be compared to the heat generation in Austrian heating plants (without combined heat and power (CHP) supply) of $8602 \mathrm{GWh}$ in the year 2012 [57]. Theoretically, a share of about $40 \%$ of the thermal energy generated in plants without CHP can be additionally obtained from wastewater heat recovery at WWTPs situated within or near to settlement areas or at WWTPs with major treatment capacities so that economic feasibility appears to be attainable in spite of greater distances between heat source and heat sink. The identified potential can be extended in case that additional utilizations can be established in the vicinity of WWTPs resulting in a further increase of the potential full load hours. Predominantly, this includes process energy, that can be applied e.g., for drying of agricultural and forestry products or greenhouse vegetable or fruit production. Such consumption potentials were not considered in the calculations due to their context-specific characteristics, which would require individual case studies. Furthermore, comparing these results to the energy demand of WWTPs reveals that under current treatment technologies, WWTPs can only deliver an electricity surplus under optimum boundary conditions, e.g., with massive co-fermentation if bio-degradable waste [19,58].

The spatial analysis for the estimation of energy potentials of WWTPs demonstrated on the Austrian case can be easily transferred to other spatial conditions as it is grounded on a common database (CORINE land cover and data about WWTPs). However, more detailed input data, e.g., aggregated land use and zoning data on the level of building blocks instead of CORINE land cover data with the smallest mapping unit of 25 hectares, would lead to more precise results. If the settlement area mapping can be combined with data about the energy density of the respective land uses, another step in methodology-development could be taken. Unfortunately, reliable data about these issues is not readily available for use and has to be generated in case-by-case-studies at the moment.

It may surprise the readers that a high number of WWTPs is suitable or potentially suitable for wastewater heat recovery as the distance between energy generation and consumption and the related heat loss is usually considered one major obstacle to heat supply. However, on the one hand investigations presented in this paper revealed that WWTPs are to date located closer to settlement areas than expected. About two thirds of all Austrian WWTPs are situated in close proximity to settlement 
structures, which can be, i.a., explained by progressive land-consuming settlement development outside of village and town centers and the related extension of residential areas (i.e., urban sprawl) as well as the inclusion of industrial and commercial land uses in the survey. On the other hand, low temperature district heating technologies help to bridge distance gaps [59]. The authors assume that the advantages of wastewater heat recovery at the effluent of a WWTP (e.g., no impacts on treatment performance, cooling of the effluent) offset the above-mentioned disadvantages.

Several studies judge the potentials mainly in relation to the wastewater quantity and temperature $[60,61]$. In the presented study, two more features are introduced: (1) the authors intend to search for existing mixed-function areas in certain distance categories to the WWTPs for the energy supply, so that the estimated full-load hours can be increased to at least 4500; (2) As potential consumers are located in mixed-function areas of a certain size, which very likely also have spatial development potentials, additional land uses and consumers can be introduced, may they be residential, industrial, commercial or agricultural depending on the quality of the location. Due to this integrated spatial and energy planning approach, the results of the presented methodology cannot be directly compared to existing wastewater-focused studies, as the system boundaries for the survey are widened.

\subsection{Environmental Evaluation of Wastewater Heat Recovery}

Assuming that the entirely estimated thermal potential of wastewater heat recovery in the amount of $3144 \mathrm{GWh} / \mathrm{a}$ can be realized, enormous reductions of the SPI-footprint as well as $\mathrm{CO}_{2}$ emissions and GWP can be achieved by substituting heat generation based on fossil energy sources, e.g., natural gas through heat generation via heat exchanger and heat pump. In case of an application of the average Austrian electricity mix, the SPI-footprint could be cut in half and $\mathrm{CO}_{2}$-emissions as well as GWP could be reduced to one third of the amount of the respective fossil supply.

Realizing the thermal energy potentials at all WWTPs classified as suitable for heating supply in their surroundings (2316 GWh/a at 173 WWTPs) would reduce the SPI-footprint in an extent of about $87,000 \mathrm{~km}^{2}$ in case of average electricity mix application and of about $165,000 \mathrm{~km}^{2}$ in case of the renewable based electricity mix. The possible footprint reduction when exploiting the entire thermal potential including also conditionally suitable WWTPs, would range from 119,000 up to 225,000 $\mathrm{km}^{2}$.

In case of an application of the average Austrian electricity mix, the possible $\mathrm{CO}_{2}$-emission reduction ranges from 741,000 tons at all WWTPs characterized as suitable for the supply of district heating systems up to about 1 million tons when including also conditionally suitable WWTPs. Heat supply based on a renewable electricity mix would lead to a reduction in the range of 1.1 million tons up to 1.5 million tons of $\mathrm{CO}_{2}$-emissions. The enormous reduction potential can be illustrated by the comparison with the annual amount of the Austrian $\mathrm{CO}_{2}$-emissions for room heating and other small consumption of about 9.5 million tons in 2012 and 10.8 million tons of $\mathrm{CO}_{2}$ equivalents in the average of the last five years [62]. In case of the GWP, the reduction potential ranges from 880,000 tons to 1.2 million tons for the average Austrian electricity mix and from 1.3 to 1.8 million tons for the renewable resource driven electricity mix so that up to $17 \%$ of the Austrian GWP for room heating can be reduced by the proposed and feasible application of WWTPs waste energy via heat pumps.

In order to realize this potential, an increase of electricity generation of about $800 \mathrm{GWh}$ is necessary. Taking the average Austrian electricity generation capacity of a $3 \mathrm{MW}$ spin wheel into consideration, 
the full wastewater energy potential can be realized with the electricity generation of about 115 wind turbines-about the average yearly installed wind power capacity in Austria of the last years. Utilizing wind power would also lead to the most favorable SPI-footprint, $\mathrm{CO}_{2}$-emission and GWP reductions when implementing wastewater energy generation with heat pumps at a large scale.

In addition to these ecological aspects of sustainability, also economic issues should be mentioned. Providing a comparable amount of thermal energy by heating systems based on natural gas, a significant cash flow to foreign countries has to be taken into account. Calculated with an average import price for natural gas of 2.5 cent per $\mathrm{kWh}$ [63] costs of about 79 million EUR per year incur to provide the same amount of thermal energy as from wastewater recovery via natural gas based heating supply. This sum amounts to around $21 \%$ of the Austrian primary sales of 369 million EUR in the sector heat pumps including investment and operation effects in 2013 [64].

\section{Conclusions}

As demonstrated by the case study of the Austrian WWTP inventory, a methodology was developed for mapping thermal energy resource potentials from WWTPs. In the first instance, these potentials are available for internal utilization at the WWTP, but in case of surpluses can provide for (thermal) energy supply in the vicinity of the site, e.g., via exploitation of wastewater energy via heat extraction from the effluent. Therefore, taking into account spatial contexts as introduced in the presented method can provide for more precise results as a basis for decision making in integrated spatial and energy planning.

The presented methodology provides a valuable framework for the mapping of energy and resource potentials from WWTPs, as it is possible to illustrate the dimension of energy supply potentials in the light of the spatial contexts of the respective WWTPs. Subsequently, these estimations can be refined target-oriented in detailed planning processes. A well-founded examination with localized waste heat potentials from wastewater energy extraction leads to a quality enhancement of conventional energy concepts by interlinking spatial and energy planning. Furthermore, the same approach can be used for the evaluation of heat recovery potentials from sewers, as the integration of energy provision and demand patterns in spatial contexts are transferrable. The method proposed here would allow for a shift from a building-centered to a neighborhood-centered approach. Further research would be needed to define suitable energy densities for the evaluation of an economic supply of mixed-function areas within urban structures as main consumers of energy resource potentials from sewers.

From the distribution of the estimated thermal energy potentials, concrete suggestions can be derived for the initialization of wastewater energy utilization. In the Austrian case, only 49 WWTPs with a treatment capacity above $50,000 \mathrm{PE}$ can provide about $60 \%$ of the estimated wastewater energy potentials. Further $15 \%$ of the thermal potential can be generated at another 124 WWTPs in size category 2 (5000 to 50,000 PE). Thus, addressing a manageable target group of 173 WWTPs, and the relevant stakeholders and actors, can exploit about three quarters of the estimated thermal energy potential.

Extracting energy from wastewater means to make a promising, not yet widely prevalent source of energy accessible that can substantially contribute to the transformation of the current fossil based to a renewable source based energy system. Thermal energy from wastewater is steadily available due to the fact that wastewater effluent is discharged continuously and, therefore, comprises a suitable energy source for grid-bound energy supply in district heating systems in multifunctional structures combined 
with additional heating and cooling demands, e.g., dewatering of agricultural and forestry products. Energy recovery from wastewater treatment increases energy efficiency and can result in greenhouse gas emission reduction as conventional fossil energy sources are substituted. Even though additional electricity is needed for the heat generation from wastewater via heat exchangers and heat pumps, substantial reductions of $\mathrm{CO}_{2}$-emission and the GWP can be achieved.

\section{Acknowledgments}

The research presented in this paper is carried out under the project "Wastewater Energy-Integration of Wastewater Infrastructure into Regional Energy Supply Concepts". This project is funded by the Austrian Climate and Energy fund within the framework of the program "e!MISSION.at" (Project Number 838716).

\section{Author Contributions}

This paper was jointly elaborated and all authors equally contributed to the results, Georg Neugebauer and Gernot Stoeglehner from the viewpoint of integrated energy and spatial planning, Florian Kretschmer and Thomas Ertl from the perspective of wastewater treatment and wastewater energy exploitation and René Kollmann and Michael Narodoslawsky from a technological and environmental evaluation view point.

\section{Conflicts of Interest}

The authors declare no conflict of interest.

\section{References}

1. Culha, O.; Gunerhan, H.; Biyik, E.; Ekren, O.; Hepbasli, A. Heat exchanger applications in wastewater source heat pumps for buildings: A key review. Energy Build. 2015, 104, 215-232.

2. Mo, W.; Zhang, Q. Energy-nutrients-water nexus: Integrated resource recovery in municipal wastewater treatment plants. J. Environ. Manag. 2013, 127, 255-267.

3. Funamizu, N.; Iida, M.; Sakakura, Y.; Takakuwa, T. Reuse of heat energy in wastewater: Implementation examples in Japan. Water Sci. Technol. 2001, 43, 277-285.

4. Bischofberger, T.; Lendi, B.; Thöny, A.; Bühler, H.; Dettli, R.; Bättig, M. Arbeitshilfe zur Erstellung einer Richtplanung Energie für Gemeinden des Kantons Graubünden (Guideline for the Elaboration of an Energy Structure Plan for Municipalities of the Canton Graubünden); Amt für Raumentwicklung Graubünden, Amt für Energie und Verkehr Graubünden: Chur, Switzerland, 2009; pp. 1-12. (In German)

5. Hausladen, G.; Hamacher, T. Leitfaden Energienutzungsplan (Guideline Energy Use Plan); Bayerisches Staatsministerium für Umwelt und Gesundheit, Bayerisches Staatsministerium für Wirtschaft, Infrastruktur, Verkehr und Technologie, Oberste Baubehörde im Bayerischen Staatsministerium des Inneren: München, Germany, 2011. (In German) 
6. Bundesgesetz über die Steigerung der Energieeffizienz bei Unternehmen und dem Bund (Bundes-Energieeffizienzgesetz-EEffG), BGB1. I Nr. 72/2014 (Austrian Federal Law on the Increase of Energy Efficiency). Available online: http://www.ris.bka.gv.at/GeltendeFassung.wxe? Abfrage $=$ Bundesnormen $\&$ Gesetzesnummer $=20008914$ (accessed on 14 May 2015).

7. Frijns, J.; Hofman, J.; Nederlof, M. The potential of (waste) water as energy carrier. Energy Convers. Manag. 2013, 6, 357-363.

8. Meggers, F.; Leibundgut, H. The potential of wastewater heat and exergy: Decentralized high-temperature recovery with a heat pump. Energy Build. 2011, 43, 879-886.

9. Baber, C. Tapping into waste heat. Water Environ. Technol. 2010, 22, 40-45.

10. Chae, K.-J.; Kang, J. Estimating the energy independence of a municipal wastewater treatment plant incorporating green energy resources. Energy Convers. Manag. 2013, 75, 664-672.

11. Wanner, O.; Panagiotidis, V.; Clavadetscher, P.; Siegrist, H. Effect of heat recovery from raw wastewater on nitrification and nitrogen removal in activated sludge plants. Water Res. 2005, 39, 4725-4734.

12. Dürrenmatt, D.; Wanner, O. A mathematical model to predict the effect of heat recovery on the wastewater temperature in sewers. Water Res. 2014, 48, 548-558.

13. Abdel-Aal, M.; Mohamed, M.; Smits, R.; Abdel-Aal, R.E.; de Gussem, K.; Schellart, A.; Tait, S. Predicting wastewater temperatures in sewer pipes using abductive network models. Water Sci. Technol. 2015, 71, 89-96.

14. Koch, M.; Nietlisbach, A.; Känel, B.; Calderoni, M.; Wille, B.; Müller, R.; Bretscher, P.; Wanner, O.; Siegrist, H.; Peter, A.; et al. Heizen und Kühlen mit Abwasser-Leitfaden für die Planung, Bewilligung und Realisierung von Anlagen zur Abwasserenergienutzung (Heating and Cooling with Wastewater-Guideline for Planning, Permission and Realisation of Wastewater Energy Recovery Systems); Baudirektion Kanton Zürich, Amt für Abfall, Wasser, Energie und Luft des Kantons Zürich: Zürich, Switzerland, 2010. (In German)

15. Haberkern, B.; Maier, W.; Schneider, U. Steigerung der Energieeffizienz auf Kommunalen Kläranlagen (Enhanced Energy Efficiency in Waste Water Treatment Plants); Federal Environmental Agency: Dessau-Roßlau, Germany, 2008; pp. 196-202. (In German)

16. Lindtner, S. Leitfaden für die Erstellung Eines Energiekonzeptes Kommunaler Kläranlagen (Guideline for the Development of an Energy Concept for Municipal Wastewater Treatment Plants); Austrian Federal Ministry of Agriculture and Forestry, Environment and Water Management: Vienna, Austria, 2008; pp. 11-23. (In German)

17. Kollmann, R.; Maier, S.; Shahzad, K.; Kretschmer, F.; Neugebauer, G.; Stoeglehner, G.; Ertl, T.; Narodoslawsky, M. Waste Water Treatment Plants as Regional Energy Cells-Evaluation of Economic and Ecologic Potentials in Austria. Chem. Eng. Trans. 2014, 39, 607-612.

18. Kretschmer, F.; Neugebauer, G.; Kollmann, R.; Eder, M.; Zach, F.; Zottl, A.; Narodoslawsky, M.; Stoeglehner, G.; Ertl, T. Resource Recovery from Wastewater in Austria-Wastewater Treatment Plants as Regional Energy Cells. In Proceedings of the IWA World Water Congress and Exhibition, Lisbon, Portugal, 21-26 September 2014.

19. Nowak, O.; Enderle, P.; Varbanov, P. Ways to optimize the energy balance of municipal wastewater systems: Lessons learned from Austrian applications. J. Clean. Prod. 2015, 88, 125-131. 
20. Batstone, D.J.; Hülsen, T.; Mehta, C.M.; Keller, J. Platforms for energy and nutrient recovery from domestic wastewater: A review. Chemosphere 2015, 140, 2-11.

21. Stillwell, A.; Hoppock, D.C.; Webber, M.E. Energy Recovery from Wastewater Treatment Plants in the United States: A Case Study of the Energy-Water Nexus. Sustainability 2010, 2, 945-962.

22. Kretschmer, F.; Weissenbacher, N.; Ertl, T. Integration of Wastewater Treatment Plants into Regional Energy Supply Concepts. Sustain. Sanit. Pract. 2015, 22, 4-9.

23. Narodoslawsky, M.; Niederl-Schmidinger, A.; Halasz, L. Utilising renewable resources economically: New challenges and chances for process development. J. Clean. Prod. 2008, 16, 164-170.

24. Neugebauer, G.; Stoeglehner, G. Realising energy potentials from wastewater by integrating spatial and energy planning. Sustain. Sanit. Pract. 2015, 22, 15-21.

25. Ochsner, K.; Adelberger, G.; Ertl, T.; Kretschmer, F.; Müller, E.A.; Penthor, A.; Zach, F. Energie aus Abwasser. Abwasser-Wärme- und Kältenutzung Mittels Hocheffizienter Großwärmepumpen (Energy from Wastewater. Heat and Cold Extraction from Wastewater Using High Efficiency Heat Pumps). Available online: https:/www.klimafonds.gv.at/assets/Uploads/Blue-Globe-Reports/ Erneuerbare-Energien/2012-2013/BGR0022013EEneueEnergien2020.pdf (accessed on 21 September 2015). (In German)

26. Kind, E.; Levy, G.A. Energieeffizienz und Energieproduktion auf ARA (Energy Efficiency and Energy Generation at WWTP); Swiss Federal Office of the Environment: Bern, Switzerland, 2012. (In German)

27. Müller, E.; Schmid, F.; Kobel, B.; Stadtmeister, W. Heizen und Kühlen mit Abwasser-Ratgeber für Bauträger und Kommunen (Heating and Cooling with Wastewater-Guideline for Building Project Organisers and Communities); Deutsche Bundesstiftung Umwelt, Bundesverband Wärmepumpen e.V., Institut für Energie in Infrastrukturanlagen: Osnabrück, Germany, 2009.

28. Venkatesh, C.; Brattebø, H. Energy consumption, costs and environmental impacts for urban water cycle services: Case study of Oslo (Norway). Energy 2011, 36, 792-800.

29. Pandis Iveroth, S.; Vernay, A.L.; Mulder, K.F.; Brandt, N. Implications of systems integration at the urban level: The case of Hammarby Sjöstad, Stockholm. J. Clean. Prod. 2013, 48, 220-231.

30. Müller, E.; Kobel, B.; Graf, E.; Roth, Y.; Müller, K.; Billmaier, K.; Lambauer, J.; Makowezki, V.; Blesl, M.; Fahl, U. Untersuchungen der Voraussetzungen für Projekte zur Wärmerückgewinnung aus dem Abwasser (Investigations on the Conditions for Projects Using Heat Recovery from Wastewater); Institut Energie Infrastrukturanlagen: Winterthur, Switzerland, 2010.

31. Müller, E.A.; Butz, J. Abwasserwärmenutzung in Deutschland: Aktueller Stand und Ausblick (Wastewater heat recovery in Germany: Current status and future prospects). KA Korresp. Abwasser Abfall 2010, 57, 437-442. (In German)

32. Knüsel, P. Räumliche Energieplanung (Spatial energy planning). Raum Umw. 2011, 3, 1-24. (In German)

33. Stoeglehner, G.; Niemetz, N.; Kettl, K.-H. Spatial dimensions of sustainable energy systems: New visions for integrated spatial and energy planning. Energy Sustain. Soc. 2011, 1, doi:10.1186/2192-0567-1-2. 
34. Stoeglehner, G.; Baaske, W.; Mitter, H.; Niemetz, N.; Kettl, K.-H.; Weiss, M.; Lancaster, B.; Neugebauer, G. Sustainability appraisal of residential energy demand and supply-A life cycle approach including heating, electricity, embodied energy and mobility. Energy Sustain. Soc. 2014, 4, doi:10.1186/s13705-014-0024-6.

35. Überreiter, E.; Stork, C.; Windhofer, G.; Zieritz, I. Kommunales Abwasser. Österreichischer Bericht 2014 (Communal Wastewater. Austrian Report 2014); Austrian Federal Ministry of Agriculture and Forestry, Environment and Water Management: Vienna, Austria, 2014. (In German)

36. EmRegV-OW-Verordnung des Bundesministers für Land-und Forstwirtschaft, Umwelt und Wasserwirtschaft über ein elektronisches Register zur Erfassung aller wesentlichen Belastungen von Oberflächenwasserkörpern durch Emissionen von Stoffen aus Punktquellen (Regulation of the Federal Minister for Agriculture and Forestry, Environment and Water Management on a Electronic Register for Recording All Significant Surface Water Pollutions through Emissions of Substances from Point Sources), BGBL II 29/2009. Available online: http://www.ris.bka.gv.at/Dokumente/ BgblAuth/BGBLA_2009_II_29/BGBLA_2009_II_29.html (accessed on 14 May 2015).

37. BMLFUW, UBA-Austrian Federal Ministry of Agriculture and Forestry, Environment and Water Management, Environment Agency Austria. Position Coordinates, Treatment Capacities and Annual Runoff of Austrian Wastewater Treatment Plants, Data Status Council Directive 91/271/EEC Concerning Urban Wastewater Treatment-Austrian Report 2014. 2015, unpublished work.

38. AEV für kommunales Abwasser-Verordnung des Bundesministers für Land-und Forstwirtschaft über die Begrenzung von Abwasseremissionen aus Abwasserreinigungsanlagen für Siedlungsgebiete (Order of the Federal Minister for Agriculture and Forestry on the limitation of wastewater emissions from wastewater treatment plants for settlement areas), BGB1. 210/1996. Available online: http://www.ris.bka.gv.at/GeltendeFassung.wxe?Abfrage=Bundesnormen\&Gesetzesnummer=1001 0980 (accessed on 14 May 2015).

39. Spatzierer, G. Nachbarschafts-und Kläranlagenliste (List of wastewater treatment plants and neighborhoods). In Kanal-und Kläranlagennachbarschaften; Folge 22; Austrian Water and Waste Management Association: Vienna, Austria, 2014. (In German)

40. Communal Wastewater Treatment Plants. Available online: http://wisa.bmlfuw.gv.at/wasserkarten/ sonstige_themen/kommunale_klaeranlagen.html (accessed on 28 May 2015).

41. CORINE land cover 2012 for Austria. Available online: http://www.umweltbundesamt.at/ umweltsituation/umweltinfo/opendata/oed_landbedeckung/ (accessed on 28 May 2015).

42. European Commission Directorate General Joint Research Center; European Environment Agency. CORINE Land Cover Technical Guide; European Environment Agency: Copenhagen, Denmark, 1999.

43. Buri, R.; Kobel, B. Energie aus Kanalabwasser. Leitfaden für Ingenieure und Planer. (Energy from Wastewater. Guideline for Engineers and Planners); Deutsche Bundesstiftung Umwelt: Osnabrück, Germany, 2005. (In German)

44. Otter, P.; Raber, W.; Wichmann, K. Heizwerk Abwasser-Abwärme. Fachinformation für Aufbau und Betrieb des Heizwerks Abwasser-Abwärme. (Heating Plant Wastewater-Wasteheat. Subject Information for Developing and Operating the Heating Plant Wastewater-Wasteheat); Forschungsverbund, RePro-Ressourcen vom Land: Berlin, Germany, 2013. (In German) 
45. Bucar, G.; Schweyer, K.; Fink, C.; Riva, R.; Neuhäuser, M.; Meissner, E.; Streicher, W.; Halmdienst, C. Dezentrale erneuerbare Energie für bestehende Fernwärmenetze. Berichte Energy Umweltforsch. 2006, 78, 1-156. (In German)

46. Wien Energie Blog. Unsere Kräftigsten Teil 3: Kraftwerk Donaustadt. Available online: http://blog.wienenergie.at/2013/04/15/unsere-kraftigsten-teil-3-kraftwerk-donaustadt/ (accessed on 1 April 2015).

47. Bühler, R.; Gabathuler, H.R.; Mayer, H. Situationserfassung mit EXCEL-Tabelle. Qualitätsmanagement Holzheizwerke, Manual, Version 18.1. Available online: http:// www.qmholzheizwerke.at/fileadmin/sites/qm/files/04_Situationserfassung/Situationserfassung_M anual_de.pdf (accessed on 14 May 2015).

48. Narodoslawsky, M.; Stoeglehner, G. Planning for Local and Regional Energy Strategies with the Ecological Footprint. J. Environ. Policy Plan. 2010, 12, 363-379.

49. Curran, M.A. Life Cycle Assessment: A review of the methodology and its application to sustainability. Curr. Opin. Chem. Eng. 2013, 2, 273-277.

50. Sandin, G.; Clancy, G.; Heimersson, S.; Peters, G.M.; Svanström, M.; Ten Hoeve, M. Making the most of LCA in technical inter-organizational R\&D projects. J. Clean. Prod. 2014, 70, 97-104.

51. Narodoslawsky, M. From processes to life cycles to technology networks-New challenges for LCA in chemical engineering. Curr. Opin. Chem. Eng. 2013, 2, 282-285.

52. Cuček, L.; Klemes, J.J.; Kravanja, Z. A Review of Footprint analysis tools for monitoring impacts on sustainability. J. Clean. Prod. 2012, 34, 9-20, doi:10.1016/j.jclepro.2012.02.036.

53. ISO. ISO-Norm, Environmental Management_Life Cycle Assessment_Principles and Framework ISO 14040:2006; ISO: Geneva, Switzerland, 2006.

54. Kettl, K.-H. Evaluation of Energy Technology Systems Based on Renewable Resources. Ph.D. Thesis, Institute for Process and Particle Engineering, Graz University of Technology, Graz, Austria, 2012.

55. Kettl, K.-H. SPIonWeb Advanced Sustainable Process Index, Calculation Software, Manual and Software Structure; Version 1.1; Graz University of Technology: Graz, Austria, 2013; pp. 1-30. Available online: http://spionweb.tugraz.at/SPIonWeb_Manual_eng.pdf (accessed on 28 May 2015).

56. SPIonWeb (Sustainable Process Index on Web). Available online: http://spionweb.tugraz.at (accessed on 14 May 2015).

57. BMWFW-Austrian Federal Ministry of Science, Research and Economy. Energiestatus Österreich 2014 (Energy Status Quo Austria 2014); BMWFW: Vienna, Austria, 2014. Available online: http://www.bmwfw.gv.at/EnergieUndBergbau/Energieeffizienz/PublishingImages/ Energiestatus\%20\%C3\%96sterreich\%202014_HP-Version.pdf (accessed on 28 May 2015).

58. Wett, B.; Bucher, K.; Fimml, C. Energy self-sufficiency as a feasible concept for wastewater treatment systems. Asian Water 2007, 9, 22-25.

59. Olsen, P.K.; Lambertsen, H.; Hummelshøj, R.; Bøhm, B.; Christiansen, C.H.; Svendsen, S.; Larsen, C.T.; Worm, J. A New Low-Temperature District Heating System for Low-Energy Buildings. In Proceedings of the 11th International Symposium on District Heating and Cooling, Reykjavik, Iceland, 31 August-2 September 2008. 
60. Bucar, G.; Schinnerl, D. Technisches und Wirtschaftliches Marktpotenzial der Wärmeenergienutzung aus dem Abwasser in Österreich-Gesamtanalyze für Österreich und Spezifische Analyze Fuer zwei Unterschiedliche Gemeinden (Technical and Economic Market Potential of Heat Extraction from Wastewater in Austria-Overall Analysis for Austria and Specific Analysis for Two Different Communities); Grazer Energieagentur GmbH: Graz, Austria, 2007.

61. Dehoust, G.; Mehlhardt, G.; Vogt, R.; Otter, P. Ausgewählte Klimaschutzpotenziale der Abwasserwirtschaft. Wärmepotenzial aus Abwasser. Potenzial der Faulgasnutzung (Selected Climate Protection Potentials of the Wastewater Management Industry. Heat Potential from Wastewater. Potential of Digester Gas Utilization); Institut für angewandte Ökologie: Darmstadt, Germany; Institut für Energie-und Umweltforschung: Heidelberg, Germany, 2010.

62. Anderl, M.; Bednar, W.; Gössl, M.; Haider, S.; Heller, C.; Jobstmann, H.; Lampert, C.; Moosmann, L.; Pazdernik, K.; Poupa, S.; et al. Klimaschutzbericht 2014 (Climate Protection Report 2014); Environment Agency Austria: Vienna, Austria, 2014.

63. Ergebnisse Industriegaspreise (Industrial Gas Prices). Available online: http://www.e-control.at/de/ industrie/gas/gaspreis/industriegaspreise/energiepreis (accessed on 29 May 2015).

64. Biermayr, P. Erneuerbare Energie in Zahlen. Die Entwicklung Erneuerbarer Energie in Österreich im Jahr 2013. (Renewable Energy in Figures. Development of Renewable Energy in Austria in 2013); Bundesministerium für Land- und Forstwirtschaft, Umwelt und Wasserwirtschaft: Vienna, Austria, 2014.

(C) 2015 by the authors; licensee MDPI, Basel, Switzerland. This article is an open access article distributed under the terms and conditions of the Creative Commons Attribution license (http://creativecommons.org/licenses/by/4.0/). 